http://dx.doi.org/10.11646/phytotaxa.81.1.10

\title{
New combinations in Pleradenophora (Euphorbiaceae s.s.)
}

\author{
ANDRÉ LAURÊNIO DE MELO ${ }^{1}$, HANS-JOACHIM ESSER ${ }^{2} \&$ MARGARETH FERREIRA DE SALES $^{3}$ \\ ${ }^{1}$ Unidade Acadêmica de Serra Talhada, Universidade Federal Rural de Pernambuco. Fazenda Saco, s/n, Serra Talhada, Pernambuco, \\ Brasil, CEP 56900-000; e-mail: andrelaurenio@yahoo.com.br \\ ${ }^{2}$ Botanische Staatssammlung München, Menzinger Str.67, D-80638 München, Germany; e-mail: esser@bsm.mwn.de \\ ${ }^{3}$ Departamento de Biologia, Área de Botânica, Universidade Federal Rural de Pernambuco, Av. D. Manuel de Medeiros, s/n, Dois \\ Irmãos, Recife, Pernambuco, Brasil, CEP-52171-900; e-mail: mfsales65@hotmail.com
}

\begin{abstract}
A nomenclatural update is presented for the (hitherto monotypic) genus Pleradenophora. New combinations are presented for Pleradenophora bilocularis, P. lottiae, P. membranifolia, P. tikalana and P. tuerckheimiana (based on Sebastiania bilocularis, S. lottiae, S. membranifolia, S. tikalana and Sapium tuerckheimianum), and four new synonyms are proposed. A key to the species is provided. The genus currently comprises five species, distributed from the United States to Bolivia, with the highest diversity in Mexico and Guatemala.
\end{abstract}

Key words: Brazil, Central America, Hippomaneae, Mexico, Sapium, Sebastiania, United States

\section{Introduction}

The genus Pleradenophora of Euphorbiaceae, subfamily Euphorbioideae, tribe Hippomaneae was described by Esser (2001: 377), although it had been first recognized as a separate genus in the unpublished thesis of Esser (1994). In 2001 Esser published only one combination under the genus, for its type, P. longicuspis (Standley 1932: 134) Esser (2001: 377) from Belize. At that time it was already obvious that additional species were involved, such as the North-American plant known as Sebastiania bilocularis Watson (1885: 374), but the species needed a more thorough study.

During a recent revision of Sebastiania Sprengel (1821: 118) sensu stricto (sect. Eusebastiania Müller 1874: 582) by Melo (2006), more species from the southern US and northern Mesoamerica were studied that should be placed in Pleradenophora, bringing the number of species up to four. Esser (2012) indicated another, isolated species from South America, S. membranifolia Müller (1874: 679), that, together with several synonyms, should be transferred to Pleradenophora.

The species of Pleradenophora have previously been classified under Sapium Jacquin (1760: 9) and Sebastiania (e.g., by McVaugh 1995, Kruijt 1996, Steinmann \& Felger 1997, Govaerts et al. 2000). These genera can be distinguished by morphological characters of leaves, staminate flowers, fruits and seeds (Table 1). Pleradenophora differs from Sapium by, e.g., the dry seeds without an aril and by staminate flowers with usually three or more stamens (versus seeds with a red aril and staminate flowers with two stamens), and from Sebastiania by, e.g., leaves often with petiolar glands, flowers with a distinctly fused calyx at least in staminate flowers, fruits with a thicker wall, the mericarp septa with a triangular split at the base and only one vascular strand each (versus leaves usually eglandular, staminate flowers with free to only very slightly fused sepals, fruits with a thinner wall, the mericarp septa without a basal triangular split and usually three vascular strands each) (Esser 2001, 2012). 
TABLE 1. Comparison of Pleradenophora, Sapium and Sebastiania.

\begin{tabular}{|c|c|c|c|}
\hline & Pleradenophora & Sapium & Sebastiania \\
\hline Petiolar glands of leaves & often present & mostly present & absent \\
\hline Sepals of staminate flowers & distinctly fused at base & distinctly fused at base & \pm free \\
\hline Number of staminate flowers per cymule & $5-10$ & $(3-) 7-18$ & $1-3(-7)$ \\
\hline Number of stamens per flower & $2-5$ & 2 & 3 \\
\hline Pericarp of fruits & thick & thin to thick & thin \\
\hline Vascular strands on septa of mericarps & $0-1$ & $0-1$ & usually 3 \\
\hline Basal triangular split of mericarp septa & present & present to indistinct & absent \\
\hline Seed surface & dry & red aril & dry \\
\hline
\end{tabular}

Wurdack et al. (2005) included one species, 'Sebastiania bilocularis', in their molecular phylogeny of uniovulate Euphorbiaceae. As would also be suggested by morphology, Pleradenophora is placed in their clade $\mathrm{H} 2$ of non-pseudanthial (hippomanoid) Euphorbioideae, together with most of the other genera characterized by, e.g., fused staminate sepals and distinctly glandular leaves, such as Sapium.

\section{Taxonomy}

Pleradenophora Esser (2001: 377).--Type: P. longicuspis (Standl.) Esser (basionym: Sebastiania longicuspis Standl.) [= Pleradenophora tuerckheimiana (Pax \& K. Hoffm.) A.L.Melo \& Esser]

\section{Key to the species of Pleradenophora}

1. Petiole with a pair of glands on the junction with the blade above 2

2. Leaves narrowly lanceolate, petiole $2-4 \mathrm{~mm}$ long; ovaries and fruits two-locular...... P. bilocularis

2'. Leaf blades ovate to elliptical, petiole 10-18 mm long; ovaries and fruits three-locular. P. tikalana

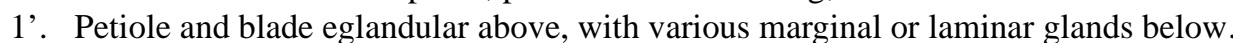

3. Leaf blades ovate, with a pair of distinct glands in basal auricles below . 3

3'. Leaf blades more or less elliptic, without distinct glands in basal auricles below

4. Leaf blades (obovate-)elliptic, indistinctly serrate, marginal glands dot-shaped, numerous, spread along the whole blade margin; style 1.0-1.4 mm long ..... P. tuerckheimiana

4'. Leaf blades (ovate-)elliptic, distinctly serrate, marginal glands cup-shaped, only 1 or 2 near the base or absent; style 9-10 mm long P. lottiae

1. Pleradenophora bilocularis (Watson) Esser \& A.L.Melo, comb. nov.

Sebastiania bilocularis Watson (1885: 374).-Sapium biloculare (Watson) Pax (in Pax \& Hoffmann 1912: 221).-Type: MEXICO. Sonora: by water courses, Northwestern mountains, 27 March 1884 (fl, fr), C. G. Pringle, Fl. Pacific Slope s.n. (lectotype GH!, isolectotypes A!, CAS!, K!, MPU!, NY!, PH!, WIS!, WU!), proposed by Steinmann \& Felger (1997: 63). Remaining syntype: MEXICO. Sonora: 1853, G. Thurber s.n. (US?).

Sapium salicifolium auct.: Torr. in Emory (1858: 201), nom. nud., based on Thurber s.n.

Sapium biloculare var. amplum Johnston (1924: 1077).—Sebastiania ampla (I.M.Johnst.) Jablonski (1968: 423).—Type: MEXICO. Baja California: Loreto, 19 May 1921 (fl), I. M. Johnston 3772 (holotype CAS, isotypes MO!, US!).

Distribution:-United States (Arizona) and adjacent Mexico.

Note:-Steinmann \& Felger (1997) already discussed the variability and delimitation of this species. It is the only distinctly sclerophyllous species of the genus. 
2. Pleradenophora lottiae (McVaugh) A.L.Melo \& Esser, comb. nov.

Sebastiania lottiae McVaugh (1995: 208).-Type: MEXICO. Jalisco: Mpio. La Huerta, Estación Biológica CHAMELA (UNAM), Arroyo Colorado, 9 July 1985 (fem fl), F. Ayala \& E. J. Lott 37 (holotype MICH!, isotypes F!, MEXU).

Distribution:-Central and South-Western Mexico.

Note:-Pleradenophora lottiae is easily identified by its long styles, acuminate fruits, and by the presence of 1 or 2, cup-shaped glands on the leaf margins.

3. Pleradenophora membranifolia (Müll.Arg.) Esser \& A.L.Melo, comb. nov.

Sebastiania membranifolia Müller (1874: 579).—Type: BRAZIL. Minas Gerais: Serra da Chapada, without date (fr), $L$. Riedel 1179 (LE?, isotypes G!, P!).

Sapium rhombifolium Rusby (1901: 307), syn. nov_—Sebastiania rhombifolia (Rusby) Jablonski (1967: 452, pl. 4), nom. illeg. (non Müller 1874: 590).-Type: BOLIVIA. Pando: Madeira, October 1886 (fl), H.H. Rusby 1824 (holotype NY!, isotypes BM!, GH-2 sheets!, K!, NY-2 sheets!, PH!).

Sebastiania huallagensis Croizat (1943: 177), syn. nov.-Type: PERU. San Martín: Río Huallaga, Juan Jui, 400-800 m, February 1936 (fl), G. Klug 4243 (holotype A!; isotypes MO!, NY!, U!).

Distribution:-Amazonian lowlands and mesophilous forests of Peru and Bolivia, extending into Brazil (Goiás, Mato Grosso, Mato Grosso do Sul, Minas Gerais, São Paulo).

Notes:-This species was well illustrated by Jablonski (1967). It was discussed also by Esser (2012, as Sebastiania). It is the only South-American species of the genus. Morphologically, in particular the peculiar leaf glands [which are shared with completely different genera, such as Dendrothrix Esser (1993: 245)] are unique in the genus, but in so many other characters the species agrees with Pleradenophora that this combination seems justified. The species is certainly isolated in South-American Hippomaneae.

4. Pleradenophora tikalana (Lundell) A.L.Melo \& Esser, comb. nov.

Sebastiania tikalana Lundell (1960: 54).-Type: GUATEMALA. Petén: Tikál, in low forest on top of Temple III, 27 October 1959 (fr), E. Contreras 322 (holotype LL!, isotypes DAV!, F!, K!, MO!, PH!, S!).

Sebastiania cornuta McVaugh (1995: 205, 206 fig. 4), syn. nov.-Type: MEXICO. Durango: Mpio. Otaez, Otaez, frente al Rancho La Lechuguilla, ladera con bosque caducifolio en la parte baja y matorral subtropical en la superior, 1270-1700 m, 5 July 1990 (fl), E. Guizar 2347 (holotype MEXU, isotype CIIDIR!).

Distribution:- South-Eastern Mexico and Guatemala.

Note:-This species was well illustrated by McVaugh (1995) under Sebastiania cornuta. Although the author did not mention the similarities between his new species and Sebastiania tikalana, the type collection Guizar 2347 clearly belongs to Pleradenophora tikalana, and for this reason it is presented as a synonym.

5. Pleradenophora tuerckheimiana (Pax \& K.Hoffm.) A.L.Melo \& Esser, comb. nov.

Sapium tuerckheimianum Pax \& Hoffmann (1919: 61)._Sebastiania tuerckheimiana (Pax \& K. Hoffm.) Lundell (1975: 80).-Type: GUATEMALA. Alta Verapaz: Cubilquitz, $350 \mathrm{~m}$, date unknown (male fl), H. von Türckheim II 941 (= J. Donnell Smith, Pl. Guatem. 8658) (holotype B?, probably destroyed; lectotype US!, proposed here, isolectotype $\mathrm{F} !)$.

Sebastiania longicuspis Standley (1932: 134), nom. illeg.-Pleradenophora longicuspis (Standl.) Esser (2001: 377).-Type: BELIZE. Toledo Distr.: Punta Gorda, "Eldorado", 17 September 1932 (fr), W. A. Schipp 1018 (holotype F!, isotypes G!, GH!, MICH!, MO!, S!, Z!).

Sebastiania standleyana Lundell (1939: 97), nom. illeg.-Type: BELIZE. Cayo District: hillside opposite Vaca, 1 May 1938 (fl, fr), P. H. Gentle 2544 (holotype MICH!, isotypes A!, F!, G!, GH!, NY!).

Sebastiania confusa Lundell (1939: 99), syn. nov.-Type: BELIZE. Belize District: near Big Falls, Belize River, 14 June 1933 (fr), C. L. Lundell 4119 (holotype MICH!, isotypes F!, G!, S!).

Distribution:- South-Eastern Mexico, Guatemala, Belize and Honduras. 
Note:-Türckheim II 941, the type for Sapium tuerckheimianum, was cited by Standley (1932) as paratype in the protologue of his Sebastiania longicuspis, as Türckheim 8658, which however refers to the same collection (II 941 is Türckheim's own collection number, 8658 is the number in Donnell Smith's distribution series). The name of S. longicuspis is therefore illegitimate (Art. 52.1 ICBN; McNeill et al. 2006). The holotype of Sebastiania longicuspis is the collection Schipp 1018; it is composed of a branch and fruits that clearly belong to different species. The fruits are drupe-like and are not euphorbiaceous, but the caudate leaves are quite characteristic. Therefore, Lundell (1939) considered S. longicuspis an incorrect designation (a nomen confusum), and proposed a new name for the species (Sebastiania standleyana), based on the specimen Gentle 2544; Türckheim 8658 (the type of S. tuerckheimianum) was again included as paratype. The synonymy of these three species has already been mentioned by Balick et al. (2000).

Lundell (1939) also proposed the species Sebastiania confusa, distinguishing it from S. standleyana based on its short-acuminate to obtuse foliar apex (as opposed to long cuspidate in S. standleyana), staminate cymules 3-flowered (vs. 6-9-flowered), stamens 2-3 (vs. 2-6), and capsules $6 \times 10 \mathrm{~mm}$ (vs. 8-11 × 10-13 $\mathrm{mm}$ ). After analyzing both type collections, as well as other specimens, it was concluded that the characteristics Lundell considered diagnostic for $S$. confusa fall within the range of variability of Pleradenophora tuerckheimiana.

\section{Acknowledgements}

The authors would like to thank the curators and directors of the herbaria who enabled us to study their holdings or sent photographs and images that aided in our work: A, BM, BOLV, CAS, CIIDIR, DAV, F, G, GH, K, LL, LPB, M, MA, MICH, MO, NSW, NY, PH, S, U, US, USZ, WU, Z, as well as the invaluable resources of JSTOR Plants with additional type images. The study was funded by the Coordenação de Aperfeiçoamento de Pessoal de Nível Superior (CAPES) with a-doctoral grant awarded to the first author; and by the Programa de Pós-Graduação em Botânica of the Universidade Federal Rural de Pernambuco (UFRPE), Brazil. Support was made available to the second author by the European Community-Research Infrastructure Action under the FP6 Structuring the European Research Area Programme (grants AT-TAF399, SE-TAF-5042), to allow for the visit of the herbaria of the Swedish Museum of Natural History, Stockholm, the Naturhistorisches Museum Vienna and the University of Vienna.

\section{References}

Balick, M.J., Nee, M.H. \& Atha, D.E. (2000) Checklist of the vascular plants of Belize. Memoirs of the New York Botanical Garden 85, 246 pp.

Croizat, L. (1943) Novelties in American Euphorbiaceae. Journal of the Arnold Arboretum 24: 165-189.

Emory, W.H. (1858). Report on the United States and Mexican boundary survey 2. Nicholson, Washington, pp. 27-270.

Esser, H.-J. (1993) Dendrothrix, a new generic concept in Neotropical Euphorbiaceae. Novon 3: 245-251. http:// dx.doi.org/10.2307/3391462

Esser, H.-J. (1994) Systematische Studien an den Hippomaneae Adr. Jussieu ex Bartling (Euphorbiaceae), insbesondere den Mabeinae Pax \& K.Hoffm. Doctoral thesis, University of Hamburg, 305 pp., 36 pl.

Esser, H.-J. (2001) Tribes Hippomaneae, Pachystromateae, Hureae. In: Radcliffe-Smith, A., Genera Euphorbiacearum. Royal Botanic Gardens, Kew, pp. 352-398.

Esser, H.-J. (2012) The tribe Hippomaneae (Euphorbiaceae) in Brazil. Rodriguesia 63: 209-225.

Govaerts, R., Frodin, D.G. \& Radcliffe-Smith, A. (2000). World checklist and bibliography of Euphorbiaceae (and Pandaceae). Royal Botanic Gardens, Kew, 1621 pp.

Jablonski, E. (1967) Notes on Neotropical Euphorbiaceae 2. New species and transfers. Phytologia 14: 450-456.

Jablonski, E. (1968) Notes on Neotropical Euphorbiaceae 3. Synopsis of Caribbean Sapium. Phytologia 16: $393-434$.

Jacquin, N.J. (1760) Enumeratio systematica plantarum. Haak, Leiden, 41 pp.

Johnston, I.M. (1925) Expedition of the California Academy of Sciences to the Gulf of California in 1921.—The botany (the vascular plants). Proceedings of the California Academy of Sciences, series 4, 12: 951-1214. 
Kruijt, R.C. (1996). A taxononomic monograph of Sapium Jacq., Anomostachys (Baill.) Hurus., Duvigneaudia J.Léonard and Sclerocroton Hochst. (Euphorbiaceae tribe Hippomaneae). Bibliotheca Botanica 146, 109 pp.

Lundell, C.L. (1939) Studies of Mexican and Central American plants_-VII. Lloydia 2(2): 73-108.

Lundell, C.L. (1960). Plantae Mayanae-I. Notes on collections from the lowlands of Guatemala. Wrightia 2(2): 49-63.

Lundell, C.L. (1975). Studies of American Plants_-VIII. Wrightia 5(4): 73-104.

McNeill, J., Barrie, F.R., Burdet, H.M., Demoulin, V., Hawksworth, D.L., Marhold, K., Nicolson, D.H., Prado, J., Silva, P.C., Skog, J.E., Wiersema, J.H. \& Turland, N.J. (2006) International code of botanical nomenclature (Vienna Code): Adopted by the Seventeenth International Botanical Congress Vienna, Austria, July 2005. Regnum Vegetabile 146. Gantner Verlag, Ruggell, 568 pp.

McVaugh, R. (1995) Euphorbiacearum sertum novo-galicianarum revisarum. Contributions from the University of Michigan Herbarium 20: 173-215.

Melo, A.L. (2006). Revisão de Sebastiania Spreng. sensu stricto (Euphorbiaceae - Hippomaneae). Tese de Doutorado, Universidade Federal Rural de Pernambuco, Recife, 117 pp.

Müller, J. (1874) Euphorbiaceae. In: Martius, C.F.P. \& Eichler, A.W. (eds) Flora Brasiliensis 11.2. Fleischer, Leipzig \& München, pp. 2-751.

Pax, F. \& Hoffmann, K. (1912). Euphorbiaceae-Hippomaneae. In: Engler, A. (ed.) Das Pflanzenreich IV.147.V (Heft 52). Engelmann, Leipzig, 319 pp.

Pax, F. \& Hoffmann, K. (1919). Euphorbiaceae-Additamentum VI. In: Engler, A. (ed.) Das Pflanzenreich IV.147.XIV (Heft 68). Engelmann, Leipzig, $81 \mathrm{pp}$.

Rusby, H.H. (1901). An enumeration of the plants collected by Dr. H.H.Rusby in South America, 1885-1886, XXXI. Bulletin of the Torrey Botanical Club 28: 301-313. http://dx.doi.org/10.2307/2478639

Sprengel, C.P.J. (1821). Neue Entdeckungen im ganzen Umfang der Pflanzenkunde 2. Fleischer, Leipzig, 363 pp.

Standley, P.C. (1932) New plants from British Honduras. Publications of the Field Museum of Natural History, Botanical series 11(4): 129-142.

Steinmann, V.W. \& Felger, R.S. (1997) The Euphorbiaceae of Sonora. Aliso 16: 1-71.

Watson, S. (1885) Contributions to American botany. Proceedings of the American Academy of Arts and Sciences 20: 324-378. http://dx.doi.org/10.2307/25138775

Wurdack, K.J., Hoffmann, P. \& Chase, M.W. (2005) Molecular phylogenetic analysis of uniovulate Euphorbiaceae (Euphorbiaceae sensu stricto) using plastid $r b c L$ and $t r n L-F$ DNA sequences. American Journal of Botany 92 : 1397-1420. http://dx.doi.org/10.3732/ajb.92.8.1397 